\title{
Ammatillinen kasvu työelämän arjessa
}

Eteläpelto Anneli \& Onnismaa Jussi (toim. 2006) . Ammatillisuus ja ammatillinen kasvu. Aikuiskasvatuksen 46. vuosikirja. Julkaisijat: Aikuiskasvatuksen Tutkimusseura ja Kansanvalistusseura. Kustajataja: Kansanvalistusseura, 277 sivua.

Ammatillisuus on vaikea käsite. Sellaisena sitä ei löydy nykysuomen sanakirjasta. Jo ammatti on suhdekäsite, toimijan kombinoitumista työhön ja tuotannon järjestelmään. Ammatillisuus nousee symbolisen tason kategoriaksi, jolloin päästään tavoittelemaan yleistä näkemystä. Onnismaan kirjoittamassa johdannossa ammatillisuus käsitetään laajasti sosiaalis-kielellisesti ja historiallisesti rakentuvaksi identiteetiksi. Ammatillisuuden, ammatillisen kasvun ja asiantuntijuuden tunnistaminen on koko kirjan teema; suurin osa 14 kirjoittajasta ilmoittaa tutkimuskohteekseen jollakin tavalla identiteetin. Kirja jakautuu kolmeen osaan: 1. Ammatillinen identiteetti ja elämäkerta, 2. Autonomia koulutusorganisaatioissa ja 3. Ammatillisen kasvun tukeminen.

Ensimmäisessäosassa Anneli Eteläpelto ja Katja Vähäsantanen pohjaavat käsityksensä jälkimodernin muutoksiin, jotka johtavat persoonallisen yhä tiiviimpään kytkeytymiseen muutoin sosiaalisesta rakentuvaan identiteettiin. Ammatillisen identiteetin rakentumista tulisikin tarkastella sosiaalisen ja persoonallisen vuoropuheluna. Artikkelissa kuvataan lyhyesti työn historiallista muutosta ja käsitetään tuotantotapojen muodostavan perustan identiteetin rakentumiselle, oppimiselle. Sosiaalisen ja persoonal- lisen välittyneisyyden tarkastelun kautta edetään oppimisnäkemykseen, jossa käytäntöyhteisöjen nähdään muodostavan näitä edellisiä integroivan kontekstin. Puhtaasti sosiokulttuurista ja situationaalista näkemystä kritisoiden pyritään hakemaan vastausta narratiivisesta otteesta, josta avautuu näkökulma tarkastella identiteettejä ilman, että yksilöllisyys menetetään.

Eero Ropo ja Anna-Maija Gustafsson tarkastelevat identiteettejä elämäkerrallisesta näkökulmasta. Elämäkertatutkimuksessa ihmiset asettuvat positioimaan ja näin identifioimaan itseään kertomisen kautta puheessa, jossa identiteetti rakentuu ja välittyy tarinana. Ammatillinen identiteetti ei muodostu yhtenäiseksi kokonaisuudeksi, vaan se on monikasvoinen. Tähän juuri tarinat ja kertominen antavat hyvän mahdollisuuden. Identiteettipositiointeja on artikkelissa kuvattu empiirisen materiaalin avulla, jotka tukevat myös oppimisen monikasvoista esille tulemista uusien (konkreettisten) positioiden ottamisen kautta. Sekä uudet ammatilliset positiot että kerronnassa otetut positiot auttavat näkemään itseä uusista näkökulmista ja näin myös oppimaan. Ammatillisuuden reflektointi on aika ajoin tarpeen, jotta elämäkerta jäsentyy myös sisäiseksi identifikaatioksi.
Pentti Hakkarainen ja Paul Jääskeläinen kokoavat tiiviissä tulkinnassaan perusteita sen erottamiseksi, että osaaminen on yksilön taitoa, mutta ammatinhallinta usean toimijan yhteisvaikutusta. Asiaa lähestytään mielekkyyden käsitteen kautta, joka on sekä klassisessa pragmatismissa että kirjoittajien vahvasti artikkelissaan esiin nostaman Vygotskin teorioissa olennainen sosiaalisen ja psyykkisen välityskategoria. Mielenkiintoisella tavalla artikkeli nostaa - muutoin kehittävän työntutkimuksen perinteessä vähälle jääneen - subjektin ja toimijan sekä yhteisön tavallaan toiminnan kohteiden kehittämisen ensimmäiseksi kohteeksi. Empiirisessä materiaalissa asia tulee esille kuvauksina, joissa työntekijät konkreettisten peilausten (videoidut työtilanteet) alkavat hahmottaa toimintansa todellisuutta vakiintuneista käsityksistään poikkeavasti. Oman arkitoiminnan ja -puheen sekä käsitysten ristiriitaisuuksien näkeminen johtaa sekä toiminnan muutosten aloitteen ottamiseen omiin käsiin ja vuorovaikutuksen muutoksen tekemiseen itse työssä. Päätelminä kirjoittajat otaksuvat, että persoonallisuuden muutos on ammatillisen kehityksen edellytys ja ammatinhallinnan kehitys edellyttää työntekijöiden omaa kehitystä. Tämä on myös mielekkyyden semioottinen perusta, josta työn "objektiiviset" kohteet nousevat uudella tavalla koko työyhteisön hallintaan. Dialogisia työpajoja ehdotetaan seuraavaksi ekspansiok- 
si ammatinhallinnan muutospyrkimyksiin.

Pekka Ruohotien näkemys avautuu yksilön sisälle, tietoon, tietorakenteiden kognitiviseen käsittelyyn, hallintaan ja ymmärrykseen. Asiantuntijuudessa olennaista on liikkuminen kognitiivisten ja metakognitiivisten prosessien tasoilla. Muutokset näiden suhteissa ilmentävät oppimista. Myös emootioiden osalta asiantuntijuuteen kuuluu kyvykkyys liikkua metatasolla. Näitä vaatimuksia yksilöt kohtaavat työssään ja voivat sisäisen prosessoinnin avulla niitä myös itsesäädellä.

\section{Autonomia ja valta}

Toisessa osassa käsitellään autonomiaa ja sen kautta valtaa. Marjatta Vanhalakka-Ruohon mukaan koulutusorganisaatiot ovat mahdollistaneet opetusprofessioiden väljäkytkentäisen kiinnittymisen, mikä on sallinut professioihin kuuluvan vapauden. Muutos on tapahtunut kohti tiukkakytkentäisempää organisoitumista, jossa perinteisen profession alueeseen kohdistuu paineita organisaatio-osaamisen suuntaan. Mahdollisuutena tässä muutostilanteessa on nähtävä opettajien professionaalisen positivisen vapauden kehittäminen kohti monikytkentäisyyttä. Tämä merkitsee opettajien ja tutkijoiden työkuvan kehittämistä ja hybridistä kytkeytymistä verkostoihin.

Kari-Pekka Lapinoja ja Hannu L.T. Heikkinen näkevät ääri-individualistisen vapauskäsityksen olevan negatiivista "vapautta jostakin" eikä positiivista "vapautta johonkin". Opettajan ammatillisen autonomian tae on kommunikaatiosta ja julkisuudesta kiinni pitävä si- vistyksellinen aspekti, mikä toteuttaa vapautta "vierasmääräytyvyydestä" ja inmisyyttä edistävien arvojen mukaisen "alaikäisyydestä" vapauttavan järjen käytön.

\section{Miten tukea ammatillis- ta kasvua}

Kolmannessa osassa käsitellään ammatillisen kasvun tukemista. Jori Leskelän artikkeli käsittelee mentorointia. Mentoroinnin käsite saa hyvän tulkinnan periaatteiden kuvauksena ja rajojen määrittämisenä muuhun ohjaukseen. Mentorointi on hyvin persoonallinen suhde lähinnä kahden saman alan ammattilaisen välillä. Ammatillista kasvua tukeva suhde muodostuu siitä, että mentoroitava hyväksyy (yleensä kokemukseltaan) vanhemman henkilön auktoriteetikseen ammatillisissa asioissa. Kun useat ohjauksen muodot kiinnittyvät institutionalisoituneisiin rooleihin, mentorointi on pitkäaikainen persoonallinen suhde. Artikkelissa kuvataan seikkaperäisesti erään mentorointiprojektin toteuttamista, jossa on runsaasti elementtejä myös varsinaisesta uraohjauksesta.

Voimaantumisen käsite on astunut kirjaan kahden artikkelin voimalla. Salme Hänninen esittelee lähinnä morenolaisen draaman ja pienryhmätyöskentelyn periaatteiden varassa toteutettua 10 päivän kehitysohjelmaa. Ohjelmassa tutkitaan elämänkehän, arkkityyppien ja roolien kautta ryhmäläisten identiteettejä; reflektioista, tarinoista ja kohtaamisista luodaan samalla portfolioita omista kokemuksia ja voimaantumisesta. Prosessin ohjaajan roolit esitellään myös seikkaperäises- ti, jolloin itse työskentelyn kokonaisuudesta saa hyvän kuvan. Kyseinen identiteettien etsintä voi sopia hyvin esimerkiksi elämänkulun siirtymävaiheisiin, mikäli muut kontekstit eivät luontevasti mahdollista omien asioiden pohdintaa.

Heli Nurmen artikkelissa voimaantuminen on liitetty verkkovuorovaikutukseen. Nurmi perustelee voimaantumisen käsitteen käyttöä sillä, että verkkovuorovaikutuksessa liikutaan syvemmällä persoonallisuudessa kuin vain taitojen hankinnassa. Artikkeli perustuu ammatillisen opettajankoulutuksen osana toteutettuun verkko-opintojaksoon, jossa opettajuuteen voimaantuminen on käsitetty koulutuksen ydinprosessiksi. Artikkelissa kuvataan opintoviikon mittaisen, oppimisalustalle rakennetun toteutuksen lähtökohtia, ohjausta ja opiskelijoille lopuksi kohdistetun kyselyn kautta voimaantumisen askeleita ja voimaantumisen tekijöitä.

Kirjan viimeisessä artikkelissaAnne Sivonen kuvaa elämänkarttaa konkreettisena välineenä elämäntilanteen kartoittamiseksi oppisopimuskoulutuksessa. Väline on käyttökelpoinen ja antoisa kaikissa opinnoissa, joissa kartoitetaan osaamista, opiskelijan lähtökohtia ja eri elämänalueiden välistä dynamiikkaa ja merkityksiä. Sivosen mukaan elämänkentän kartoitus sopii erityisesti opintojen ja kehittämiskohteiden paikantamisen alkuun eli suunnitteluvaiheisiin. Se on luontevasti myös HOPSien tai henkilökohtaisten kehittymissuunnitelmien tekemisen välineistöä erilaisissa oppimis- tai kehittämistilanteissa. Elämänkartta ei ole testaava tai diagnostinen väli- 
ne, vaan vuorovaikutuksessa ohjaajan ja ohjattavan kanssa yhteisesti kohdetta rakentava dialogin väline.

Kirja sisältää hyvää välineistöä ammatillisen kasvun tukemisen ajatteluun, vuorovaikutustilanteiden tarpeen ymmärtämiseen ja jopa konkreettisia interventiovälineitä. Etenkin kasvatus- ja inmistyön ammattilaisille kirjan tarjoama kuva ammatillisen kasvun erilaisista tekijöistä, rakentavista metodeista saattaa avata jonkin uuden oven. Artikkelit ovat erillisiä ja toisiaan täydentäviä, joten sivistynyt lukija muodostaa niistä oman kokonaisuutensa. Minulle sen sijaan kirjassa olisi saanut olla enemmän hahmotusta ammatillisuuden ja ammattilaisuuden kasvun reaalisesta kontekstista.

Ammatillisuus ja ammatillinen kasvu tapahtuvat työelämän arjessa ilman erillisiä interventioita; sen kaikkia puolia on vaikea myös avata hetkellisen diskurssi- tai tarinaikkunan kautta. Ammatillisuutta tehdään (tuotetaan ja kulutetaan) päivästä päivään niin verstaan lattiatasolla, toimistossa kuin henkilöstöyksikön järjestämissä kehittämistilanteissa tai esimieskeskusteluissa. Pääasiassa se tapahtuu kollegiaalisena "vääntönä" työn ääressä ja sen ulkopuolella - hajautetun kognition ja asiantuntijuuden käsitteet olisivat sopineet tarkastelun kohteiksi tähänkin kirjaan.

Ammattilaisuus rakentuu kuitenkin myös oman työn ulkopuolisten "löyhien" tai "heikkojen" sidosten varassa, joista saadaan uutta materiaalia omaan työhön ja yhteisöön myös yksilöllisten kytkeytymisten kautta. Työmarkkinoilla tapahtuva ammatillisten siirtymien käsittely olisi antanut nyt hyvin rajatuksi jäävään ammatillisuuteen kontekstuaalista avaruutta. Ammatillisuuden uusi kasvualusta on työn ulkopuolella, metaforisesti ja myös reaalisesti prekariaatin maailmassa ja työsuhteissa, joissa työstä - ja samalla palkasta vapaassa toiminnassa itseä varustetaan ammattilaiseksi ja markkinakilpailuihin.

Millaisia ovat uudet kvalifikaatiot, joihin ammattilaisuus ja ammatillinen kasvu kiinnittyvät? Oppiminen tulevia potentiaalisia ammattitehtäviä varten tapahtuu yhä enemmän informaaleissa puitteissa, mutta yhä enemmän sosiaalisesti jakautuneilla ja yhdistävillä kentillä. Kuitenkin ammatillisuuteen kasvetaan ja kasvua tuetaan myös erityisissä ammatillisissa koulutuksissa, joista kirja mainitsee nyt eksplisiittisesti vain oppisopimuskoulutuksen Sivosen artikkelissa.

Nämä huomautukset eivät alenna kirjan arvoa ammatillisuudesta käytävän keskustelun jatkamiseksi.

\section{Heikki Pasanen}

